\title{
US GAAP en de jaarrekening van Nederlandse ondernemingen
}

\section{Linda Bakker en Ruud Vergoossen}

SAMENVATTING In dit artikel wordt verslag gedaan van een onderzoek naar de mate waarin Nederlandse ondernemingen met een beursnotering in de Verenigde Staten de United States Generally Accepted Accounting Principles (US GAAP) toepassen in hun in Nederland gepubliceerde jaarrekening. Daartoe is onderzocht in hoeverre deze ondernemingen in de periode 1995-2002 grondslagwijzigingen hebben doorgevoerd die leiden tot het (meer) toepassen van US GAAP en is nagegaan wat de belangrijkste verschillen tussen US GAAP en de Nederlandse verslaggevingsregels zijn zoals die blijken uit de jaarrekening 2002. Bovendien omvat het onderzoek een vergelijking van de additionele informatieverschaffing in de in Nederland gepubliceerde jaarrekening 2002 en de jaarrekening 2002 zoals opgenomen in het Form 20-F dat bij de Securities and Exchange Commission is gedeponeerd. De onderzoeksresultaten worden vergeleken met eerder soortgelijk onderzoek. Hoewel de in het onderzoek betrokken ondernemingen meer en meer waarderings- en resultaatbepalingsgrondslagen toepassen die in overeenstemming zijn met US GAAP, wordt het aantal in de aansluitingsoverzichten opgenomen afwijkingen tussen de cijfers op basis van US GAAP en die op basis van de Nederlandse verslaggevingsregels niet kleiner, maar juist groter. Daarnaast blijkt dat veel additionele informatie die in de Verenigde Staten verplicht is, ook steeds vaker terechtkomt in de in Nederland gepubliceerde jaarrekening.

Drs. R.W. Bakker is werkzaam bij Deloitte in Amsterdam. Zij studeerde bedrijfseconomie aan de Universiteit Maastricht. Prof. Dr. R.G.A. Vergoossen RA is voorzitter van het directoraat Vaktechniek van Ernst \& Young Accountants en hoogleraar Internationale Externe Berichtgeving aan de Universiteit Maastricht.

\section{Inleiding}

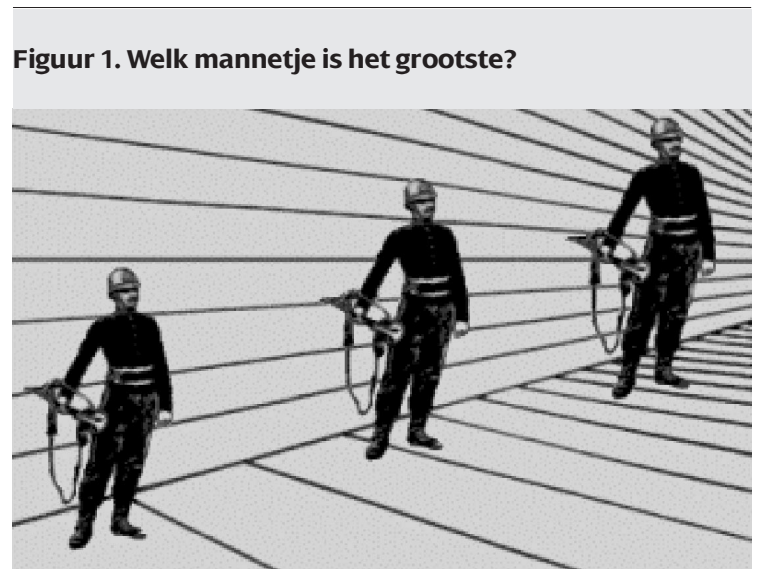

Bron: webpagina: http://www.optillusions.com/dp/1-36.htm

Drie mannetjes, het linker mannetje lijkt kleiner dan het rechter mannetje. Is dit ook zo? Nee, alle mannetjes zijn even groot. Er is hier duidelijk sprake van gezichtsbedrog. Hetzelfde mannetje is op drie verschillende plaatsen in de ruimte neergezet. Vanwege de lijnen die in de ruimte aanwezig zijn, lijkt het alsof het rechter mannetje het grootste is en er dus drie mannetjes van verschillende grootte zijn.

Iets soortgelijks doet zich voor bij Nederlandse ondernemingen met een beursnotering in de Verenigde Staten. Bij KPN bijvoorbeeld, dat aan Euronext Amsterdam en de New York Stock Exchange (NYSE) is genoteerd. KPN rapporteert over 2003 een nettowinst van $€ 2,7$ miljard op basis van de Nederlandse verslaggevingsregels en over datzelfde jaar een nettoverlies van $€ 3,8$ miljard op basis van de Amerikaanse verslaggevingsregels (United States Generally Accepted Accounting Principles; US GAAP), een verschil van ruim $240 \%$. Verschillen in verslaggevingsregels tussen landen zorgen voor (grote) verschillen in de gepresenteerde cijfers. Het linker mannetje zou 
dan bijvoorbeeld het nettoresultaat van KPN volgens US GAAP zijn en het rechter mannetje het nettoresultaat volgens de Nederlandse verslaggevingsregels. Het middelste mannetje, ten slotte, zou het nettoresultaat volgens de Duitse verslaggevingsregels kunnen zijn.

In dit artikel wordt nagegaan in hoeverre Nederlandse ondernemingen met een beursnotering in de Verenigde Staten US GAAP toepassen in hun in Nederland gepubliceerde jaarrekening. Daartoe zijn de navolgende zaken onderzocht:

- de mate waarin deze ondernemingen in hun jaarrekeningen over de jaren 1995 tot en met 2002 grondslagwijzigingen hebben doorgevoerd die leiden tot het (meer) toepassen van US GAAP;

- de belangrijkste verschillen tussen US GAAP en de Nederlandse verslaggevingsregels zoals die blijken uit de jaarrekening 2002;

- afwijkingen in de additionele informatieverschaffing in de in Nederland gepubliceerde jaarrekening 2002 en de bij de Securities and Exchange Commission (SEC) gedeponeerde jaarrekening 2002.

De onderzoeksresultaten worden vergeleken met die van Vergoossen (1996). Het onderzoek van Vergoossen behelst de periode 1984-1994. Inmiddels zijn er meer Nederlandse ondernemingen met een beursnotering in de Verenigde Staten en hebben belangriike internationale ontwikkelingen plaatsgevonden. In paragraaf 2 wordt kort ingegaan op de beursnotering van Nederlandse ondernemingen in de Verenigde Staten. Daarna worden in paragraaf 3 tot en met 5 de onderzoeksresultaten besproken. Het artikel wordt afgesloten met een aantal slotopmerkingen in paragraaf 6 .

\section{Nederlandse onderneming goes USA...}

In tabel 1 is te zien dat er ultimo 200232 Nederlandse ondernemingen met een beursnotering in de Verenigde Staten waren, 21 aan de NYSE en 11 door middel van het National Association of Securities Dealers Quotation System (NASDAQ) ${ }^{1}$. Uit de tabel komt naar voren dat het aantal Nederlandse ondernemingen met een Amerikaanse beursnotering vooral in de jaren negentig sterk is toegenomen.

Ondernemingen met een beursnotering in de Verenigde Staten vallen onder het toezicht van de SEC. Buitenlandse ondernemingen zijn verplicht jaarlijks een document op te stellen volgens het zogenaamde Form 20-F. Dit document waarin onder meer de jaarrekening is opgenomen, moet bij de SEC worden gedeponeerd. De in het Form 20-F op te nemen jaarrekening moet in beginsel worden opgesteld in overeenstemming met US GAAP die doorgaans veel omvangrijker, gedetailleerder en strikter zijn dan de Nederlandse verslaggevingsregels.

Om tegemoet te komen aan buitenlandse (nietAmerikaanse) ondernemingen biedt Form 20-F een aantal faciliteiten. Een buitenlandse onderneming hoeft bijvoorbeeld niet geheel te voldoen aan US Tabel 1. Nederlandse ondernemingen met beursnotering
in de Verenigde Staten*

\begin{tabular}{|c|c|c|}
\hline Onderneming & Notering & Jaar \\
\hline 1 Koninklijke Luchtvaart Maatschappij NV (KLM) & NYSE & 1953 \\
\hline \multicolumn{3}{|l|}{2 NV Koninklijke Nederlandsche Petroleum } \\
\hline Maatschappij (KNPM) & NYSE & 1954 \\
\hline 3 Unilever NV (Unilever) & NYSE & 1961 \\
\hline 4 Philips Electronics NV (Philips) & NYSE & 1962 \\
\hline \multicolumn{3}{|l|}{5 Advanced Semiconductor Materials } \\
\hline International NV (ASMI) & NASDAQ & 1981 \\
\hline 6 Océ NV (Océ) & NASDAQ & 1984 \\
\hline 7 AEGON NV (AEGON) & NYSE & 1985 \\
\hline 8 Akzo Nobel NV (Akzo Nobel) & NASDAQ & 1989 \\
\hline 9 Koninklijke Ahold NV (Ahold) & NYSE & 1991 \\
\hline 10 Orthofix International NV (Orthofix) & NASDAQ & 1992 \\
\hline 11 Sapiens International Corporation NV (Sapiens) & NASDAQ & 1992 \\
\hline 12 Arcadis NV (Arcadis) & NASDAQ & 1993 \\
\hline 13 Reed Elsevier NV (Reed Elsevier) & NYSE & 1994 \\
\hline 14 Koninklijke KPN NV (KPN) & NYSE & 1995 \\
\hline 15 ASM Lithography Holding NV (ASML) & NASDAQ & 1995 \\
\hline 16 BE Semiconductor Industries NV (BESI) & NASDAQ & 1995 \\
\hline 17 Triple P NV (Triple P) & NASDAQ & 1995 \\
\hline 18 Gucci Group NV (Gucci) & NYSE & 1995 \\
\hline 19 Qiagen NV (Qiagen) & NASDAQ & 1996 \\
\hline 20 ABN Amro Holding NV (ABN Amro) & NYSE & 1997 \\
\hline 21 Chicago Bridge \& Iron Company NV (Chicago Bridge) & NYSE & 1997 \\
\hline 22 ING Group NV (ING) & NYSE & 1997 \\
\hline 23 Core Laboratories NV (Core Laboratories) & NYSE & 1998 \\
\hline 24 Equant NV (Equant) & NYSE & 1998 \\
\hline 5 TPG NV (TPG) & NYSE & 1998 \\
\hline 26 CNH Global NV (CNH) & NYSE & 1999 \\
\hline 27 Crucell NV (Crucell) & NASDAQ & 2000 \\
\hline 28 Head NV (Head) & NYSE & 2000 \\
\hline 29 New Skies Satellites NV (New Skies) & NYSE & 2000 \\
\hline 30 Buhrmann NV ( Buhrmann) & NYSE & 2001 \\
\hline 31 James Hardie Industries NV ( James Hardie) & NYSE & 2001 \\
\hline 32 Van der Moolen Holding NV (Van der Moolen) & NYSE & 2001 \\
\hline
\end{tabular}


GAAP voor wat betreft de verstrekking van aanvullende informatie in de toelichting, zolang de beursnotering in de Verenigde Staten niet gepaard gaat met een aandelenemissie. Daarnaast hebben deze ondernemingen de mogelijkheid om bij het opstellen van de jaarrekening een andere set van (nationale) verslaggevingsregels te hanteren. Indien van deze optie gebruik wordt gemaakt, moeten de toegepaste verslaggevingsregels en belangrijke afwijkingen van US GAAP worden toegelicht. De invloed van deze afwijkingen op het eigen vermogen en het nettoresultaat moeten bovendien worden gekwantificeerd. Dit laatste kan geschieden in de vorm van aansluitingsoverzichten (reconciliation statements).

\section{Grondslagwijzigingen}

Om inzicht te krijgen in de mate waarin de Nederlandse ondernemingen, die in de Verenigde Staten zijn genoteerd, de bereidheid hebben zich na hun eerste notering te conformeren aan US GAAP, is onderzocht in hoeverre de betrokken ondernemingen in hun in Nederland gepubliceerde jaarrekening overgaan tot het toepassen van US GAAP. Dit is gedaan door te kijken of de grondslagwijzigingen in de periode 1995-2002 leiden tot het toepassen van meer US GAAP. De jaarrekeningen van ondernemingen die volgens de Nederlandse verslaggevingsregels hun jaarrekening opstellen, zijn onderzocht op grondslagwijzigingen. Vervolgens is gekeken of deze wijzigingen leiden tot grondslagen van waardering en resultaatbepaling die meer in overeenstemming zijn met US GAAP.

Van de 32 in het onderzoek betrokken ondernemingen passen in de onderzoeksperiode 15 ondernemingen in hun in Nederland gepubliceerde jaarrekening de Nederlandse verslaggevingsregels toe (zie tabel 2). Philips echter is met ingang van jaarrekening 2002 volledig overgestapt op US GAAP, waardoor dat aantal in 2002 daalt naar 14 (dat is $44 \%$ van de totale onderzoekspopulatie). De in Nederland gepubliceerde jaarrekening van de 17 andere ondernemingen zijn in veruit de meeste gevallen opgesteld in overeenstemming met US GAAP ${ }^{2}$.

Ten tijde van het onderzoek van Vergoossen (1996) publiceerde nog 65\% (11 van de 17 in het onderzoek betrokken ondernemingen) in Nederland een jaarrekening in overeenstemming met de Nederlandse verslaggevingsregels. Dat percentage is sindsdien gedaald naar 44 doordat vooral jonge ondernemingen, die met name in de Verenigde Staten opereren en daar nog niet zo lang een beursnotering hebben, hun in Nederland gepubliceerde jaarrekening opstellen conform US GAAP.

\begin{tabular}{|c|c|c|c|}
\hline \multirow[b]{2}{*}{ Onderneming } & \multirow[b]{2}{*}{ Onderzoeksperiode } & \multicolumn{2}{|c|}{ Aantal grondslagwijzigingen: } \\
\hline & & totaal & $\begin{array}{l}\text { waarvan meer } \\
\text { conform } \\
\text { US GAAP }\end{array}$ \\
\hline KLM & $1995-2002$ & 6 & 6 \\
\hline Unilever & $1995-2002$ & 9 & 8 \\
\hline Philips & 1995-2001 & 6 & 6 \\
\hline Océ & $1995-2002$ & 4 & 4 \\
\hline AEGON & $1995-2002$ & 5 & 2 \\
\hline Akzo Nobel & $1995-2002$ & 8 & 7 \\
\hline Ahold & $1995-2002$ & 6 & 6 \\
\hline Arcadis & $1995-2002$ & 1 & 1 \\
\hline Reed Elsevier & $1995-2002$ & 5 & 4 \\
\hline KPN & $1995-2002$ & 2 & 2 \\
\hline ABN Amro & $1997-2002$ & 4 & 3 \\
\hline ING & 1997-2002 & 7 & 6 \\
\hline TPG & 1998-2002 & 3 & 3 \\
\hline Buhrmann & $2001-2002$ & 2 & 2 \\
\hline Van der Moolen & $2001-2002$ & 4 & 4 \\
\hline Totaal & & 72 & 64 \\
\hline
\end{tabular}

In tabel 2 is per onderneming de onderzoeksperiode aangegeven en het totaal aantal wijzigingen in de grondslagen van waardering en resultaatbepaling dat in die periode door de desbetreffende onderneming is doorgevoerd. Bovendien is aangegeven hoeveel van de doorgevoerde grondslagwijzigingen leiden tot het toepassen van grondslagen die meer in overeenstemming zijn met US GAAP. Het blijkt dat van de in totaal 72 grondslagwijzigingen er $64(89 \%)$ leiden tot de toepassing van grondslagen van waardering en resultaatbepaling die meer conform US GAAP zijn. De meest voorkomende grondslagwijziging is de verandering in de behandeling van de bij acquisities betaalde goodwill, die door de meeste Nederlandse ondernemingen tot voor kort en bij sommige Nederlandse ondernemingen nog steeds direct ten laste van het eigen vermogen wordt gebracht. De meeste ondernemingen kiezen er nu voor om de goodwill te activeren en systematisch af te schrijven over de veronderstelde economische levensduur. Deze verwerkingswijze was tot voor enkele jaren voorgeschreven in de Verenigde Staten. Tegenwoordig is systematische afschrijving van geactiveerde goodwill echter niet meer toegestaan volgens US GAAP, maar moet jaarlijks worden getoetst of er sprake is van een bijzondere waardevermindering (impairment test).

Bij de motivering van de grondslagwijzigingen wordt 
meestal gerefereerd aan internationale ontwikkelingen of dat de wijziging leidt tot het toepassen van een grondslag die meer gebruikelijk is in de bedrijfstak. Door een aantal ondernemingen wordt expliciet verwezen naar US GAAP. Dit was bijvoorbeeld duidelijk het geval bij Philips dat sinds 2002 de primaire jaarrekening volledig opstelt volgens US GAAP en dat zoals uit tabel 2 blijkt - in de jaren daarvoor naar US GAAP heeft toegewerkt.

In het onderzoek van Vergoossen (1996) zijn er 30 grondslagwijzigingen, waarvan $27(90 \%)$ meer conform US GAAP. Over de periode die beide onderzoeken bestrijken (1984-2002) is er dus sprake van het steeds meer toepassen van grondslagen van waardering en resultaatbepaling die meer in overeenstemming zijn met US GAAP. Dat wil niet zeggen dat de ondernemingen zich bewust en enkel en alleen hebben laten leiden door US GAAP. Doordat verslaggevingsstelsels internationaal steeds meer naar elkaar toe groeien en de invloed van US GAAP op de regelgeving van de International Accounting Standards Board (IASB) en daarmee van de Nederlandse regelgeving groot is, leidt de toepassing van nieuwe of aangepaste internationale of nationale regelgeving veelal 'automatisch' tot meer conformiteit met US GAAP.

\section{Afwijkingen in aansluitingsoverzichten}

In de inleiding is aangegeven dat Nederlandse ondernemingen in het Form 20-F een jaarrekening mogen opnemen die volgens de Nederlandse verslaggevingsregels is opgesteld. Ze moeten dan echter wel aansluitingsoverzichten opnemen waarin zij de afwijkingen van US GAAP toelichten. De aansluitingsoverzichten geven inzicht in de verschillen die bestaan tussen de Amerikaanse en de Nederlandse verslaggevingsregels en in de effecten van deze verschillen op het gepresenteerde eigen vermogen en nettoresultaat.

In tabel 3 zijn de effecten van de verschillen weergegeven zoals die blijken uit de aansluitingsoverzichten die zijn opgenomen in de Forms $20-\mathrm{F}$ van de betrokken ondernemingen over het boekjaar 2002.

De effecten zijn vaak groot. In het boekjaar 2002 leidt toepassing van US GAAP in alle gevallen tot een hoger eigen vermogen, variërend van $+5 \%$ voor Buhrmann tot $+227 \%$ voor Ahold. Toepassing van US GAAP leidt meestal tot een lager nettoresultaat, variërend van $-314 \%$ voor ING tot $+110 \%$ voor Reed Elsevier.

Ten tijde van het onderzoek van Vergoossen (1996) is ook gekeken naar de effecten van de verschillen op het eigen vermogen en het nettoresultaat. Het blijkt dat in het boekjaar 1994 toepassing van US GAAP, vergeleken met de toepassing van de Nederlandse verslaggevingsregels, leidt tot een hoger eigen vermogen, variërend van $+1 \%$ tot $+96 \%$, en een lager nettoresultaat, variërend van $-47 \%$ tot $-2 \%$. De effecten ten opzichte van het boekjaar 1994 zijn dus behoorlijk groter geworden. Dit duidt er niet op dat er nu min-

Tabel 3. Eigen vermogen en nettoresultaat volgens Nederlandse grondslagen en US GAAP in 2002 (bedragen in miljoenen euro's)

\begin{tabular}{|c|c|c|c|c|c|c|}
\hline \multicolumn{4}{|c|}{ Eigen vermogen ultimo 2002} & \multicolumn{3}{|c|}{ Nettoresultaat over 2002} \\
\hline Onderneming & Nederlandse grondslagen & US GAAP & verschil in \% & Nederlandse grondslagen & US GAAP & verschil in \% \\
\hline KLM & 1.476 & 2.827 & 91 & -416 & -267 & 36 \\
\hline Unilever & 5.867 & 11.699 & 99 & 2.129 & 4.309 & 102 \\
\hline Océ & 908 & 1.110 & 22 & 112 & 65 & -42 \\
\hline AEGON & 14.231 & 17.554 & 23 & 1.547 & -2.230 & -244 \\
\hline Akzo Nobel & 2.098 & 5.455 & 160 & 818 & 860 & 5 \\
\hline Ahold & 2.609 & 8.541 & 227 & -1.208 & -4.328 & -258 \\
\hline Arcadis & 124 & 164 & 32 & 24 & 20 & -17 \\
\hline Reed Elsevier & 2.034 & 2.558 & 26 & 144 & 303 & 110 \\
\hline KPN & 4.508 & 10.825 & 140 & -9.542 & -15.107 & -58 \\
\hline ABN Amro & 10.781 & 19.013 & 76 & 2.207 & 2.110 & -4 \\
\hline ING & 18.254 & 25.060 & 37 & 4.500 & -9.627 & -314 \\
\hline TPG & 2.842 & 3.110 & 9 & 599 & 717 & 20 \\
\hline Buhrmann & 1.811 & 1.910 & 5 & -588 & -941 & -60 \\
\hline Van der Moolen & 312 & 523 & 68 & 58 & 27 & -53 \\
\hline
\end{tabular}




\begin{tabular}{|c|c|}
\hline $\begin{array}{l}\text { Tabel 4. Afwijkingen van US GAAP blijkend uit } \\
\text { aansluitingsoverzichten (maximaal } 14 \text { keer) }\end{array}$ & \\
\hline Afwijking van US GAAP & $\begin{array}{c}\text { Aantal } \\
\text { keer }\end{array}$ \\
\hline Verwerking betaalde goodwill & 14 \\
\hline Verwerking derivaten / financiële instrumenten & 10 \\
\hline Bepaling pensioenkosten en pensioenvoorziening & 10 \\
\hline Waardering immateriële activa, niet zijnde goodwill & 9 \\
\hline Bepaling voorzieningen in verband met reorganisatie & 7 \\
\hline Verwerking nog te declareren dividenden & 7 \\
\hline Bepaling opties / bonusplannen personeel & 5 \\
\hline Bepaling belastinglatenties & 4 \\
\hline Waardering materiële vaste activa & 4 \\
\hline Verwerking softwarekosten & 3 \\
\hline Activering financieringskosten & 3 \\
\hline Waardering beleggingen in onroerend goed & 3 \\
\hline Bepalen technische voorziening & 2 \\
\hline Verantwoording gerealiseerde winst op vastrentende waarden & 2 \\
\hline Omzetverantwoording & 2 \\
\hline Winstverantwoording sale-lease back transacties & 2 \\
\hline Afwijkingen die slechts eenmalig voorkomen & 19 \\
\hline Totaal & 106 \\
\hline
\end{tabular}

der verschillen tussen de Nederlandse verslaggevingsregels en US GAAP zijn ${ }^{3}$.

In tabel 4 zijn de afwijkingen opgenomen die uit de bestudering van de aansluitingsoverzichten naar voren komen. Daarbij is voor iedere afwijking aangegeven hoeveel van de in tabel 3 genoemde 14 ondernemingen daarvan in hun aansluitingsoverzichten melding maken.

Het blijkt dat alle 14 ondernemingen correcties aanbrengen in het aansluitingsoverzicht met betrekking tot de post goodwill. Goodwill wordt door de meeste Nederlandse ondernemingen niet langer direct ten laste van het eigen vermogen gebracht, maar geactiveerd en vervolgens lineair afgeschreven. Ondanks dat veel ondernemingen zich de afgelopen jaren meer hebben aangepast aan US GAAP wat betreft de behandeling van goodwill, blijven de verschillen uit het verleden bestaan. De stelselwijzigingen over de behandeling van goodwill zijn bijna nooit met terugwerkende kracht toegepast. De meeste ondernemingen willen daarmee voorkomen dat eerder betaalde en direct ten laste van het eigen vermogen gebrachte goodwill alsnog een drukkend effect heeft op toekomstige 'Nederlandse' winstcijfers ${ }^{4}$. De effecten op de gepresenteerde cijfers van de verschillen met betrekking tot de post goodwill werden aanvankelijk steeds kleiner, maar door de nieuwe regelgeving in de Verenigde Staten dreigen zij nu weer groter te worden omdat de ondernemingen nog steeds systematisch afschrijven op goodwill ${ }^{5}$. Voorts staan bij tien van de 14 ondernemingen derivaten/financiële instrumenten en de behandeling van pensioenen vermeld in de aansluitingsoverzichten. Hier zijn ook nog verschillen in regelgeving waar te nemen of verschillen uit het verleden staan nog in de aansluitingsoverzichten.

In totaal worden 106 afwijkingen genoemd in de aansluitingsoverzichten over het boekjaar 2002 van de 14 in het onderzoek betrokken ondernemingen. Dat is gemiddeld $8(7,57)$ per onderneming. In het onderzoek van Vergoossen (1996) is er sprake van 61 afwijkingen in de aansluitingsoverzichten over het boekjaar 1994 van 11 ondernemingen. Per onderneming is dit gemiddeld $6(5,55)$ afwijkingen.

Gezien in het licht van de internationale harmonisatie van de financiële verslaggeving die al geruime tijd plaatsvindt, is het prima vista merkwaardig dat het aantal afwijkingen in de aansluitingsoverzichten toeneemt in plaats van afneemt en dat de effecten op de gepresenteerde cijfers groter in plaats van kleiner worden. Deze contra-intuïtieve bevinding komt doordat ondernemingen vaak niet met terugwerkende kracht nieuwe regelgeving toepassen, waardoor verschillen uit het verleden blijven bestaan. Daarnaast ontstaan er nieuwe verschillen door nieuwe regelgeving in de Verenigde Staten die - al dan niet via de International Financial Reporting Standards (IFRS) - vertraagd in de Nederlandse verslaggevingsregels zijn weerslag vindt.

\section{Additionele informatieverschaffing in de toelichting}

In de Verenigde Staten zijn de verslaggevingsregels omtrent de informatieverschaffing in de toelichting veel uitgebreider en strikter geformuleerd dan in Nederland. In deze paragraaf wordt onderzocht in hoeverre toelichtingsinformatie die uitsluitend op basis van US GAAP moet worden verstrekt, is terug te vinden in de jaarrekening zoals gepubliceerd in Nederland. Daartoe zijn de in het Form 20-F (c.q. Form 10-K) over het boekjaar 2002 opgenomen jaarrekening en de bijbehorende in Nederland gepubliceerde jaarrekening van de 32 in tabel 1 genoemde ondernemingen met elkaar vergeleken. Orthofix, Chicago Bridge en Core Laboratories deponeren bij de SEC Form 10-K in plaats van Form 20-F. Form 10$\mathrm{K}$ geldt voor Amerikaanse ondernemingen en is dus niet toegespitst op en biedt geen faciliteiten aan buitenlandse ondernemingen. 
In het onderzoek worden de volgende 11 informatieelementen onderscheiden:

1 voorziening dubieuze debiteuren;

2 pensioenkosten;

3 pensioenvoorziening;

4 belastinglasten;

5 belastinglatenties;

6 langetermijnschulden;

7 operationele leaseverplichtingen;

8 risico's met betrekking tot financiële instrumenten;

9 reële waarde van financiële instrumenten;

10 segmentatie van cijfers naar bedrijfstakken;

11 segmentatie van cijfers naar geografische gebieden.

Per informatie-element zijn de corresponderende jaarrekeningen van iedere onderneming met elkaar vergeleken en is gekeken in hoeverre in beide jaarrekeningen dezelfde informatie wordt verstrekt. Het zal duidelijk zijn dat ook op andere terreinen de eisen ten aanzien van de additionele informatieverschaffing in de Verenigde Staten verder gaan dan in Nederland. We beperken ons echter tot bovengenoemde informatieelementen omdat zij een zekere algemene geldigheid bezitten, dat wil zeggen elke in het onderzoek betrokken onderneming heeft er in beginsel mee te maken.

In tabel 5 staan de 11 informatie-elementen, waarbij per informatie-element is aangegeven of het alleen in Form 20-F/10-K voorkomt of dat het ook in de Nederlandse jaarrekening is terug te vinden. De kolom 'niet verstrekt' wil zeggen dat noch de jaarrekening opgenomen in Form 20-F/10-K noch de in Nederland gepubliceerde jaarrekening het informa- tie-element bevat. Dit kan betekenen dat de in het Form 20-F/10-K opgenomen toelichtingsinformatie terecht of onterecht - niet conform US GAAP is.

In tabel 5 komt naar voren dat veel additionele informatie die volgens US GAAP verplicht is, vaak ook in de Nederlandse jaarrekening wordt vermeld. Informatie omtrent pensioenen en belastingen opgenomen in het Form 20-F/10-K wordt in vier respectievelijk vijf gevallen niet vermeld in de Nederlandse jaarrekening. Pensioenen en belastingen moeten behoorlijk uitgebreid worden toegelicht in de Verenigde Staten en sommige Nederlandse ondernemingen hebben deze informatie alleen in het Form 20-F/10-K verstrekt.

In geen enkel geval wordt in het Form 20-F/10-K meer gesegmenteerde informatie verstrekt dan in de Nederlandse jaarrekening. Zeven respectievelijk drie ondernemingen hebben expliciet aangegeven dat zij slechts in één bedrijfstak werkzaam zijn of dat de activiteiten voornamelijk zijn geconcentreerd in Nederland of de Benelux. Deze ondernemingen zijn ondergebracht in de rubriek 'niet verstrekt', wat hier eigenlijk wil zeggen 'niet van toepassing'.

In tabel 6 is voor iedere onderneming afzonderlijk aangegeven in hoeverre toelichtingsinformatie, die uitsluitend op basis van US GAAP verplicht moet worden verstrekt, ook is opgenomen in de Nederlandse jaarrekening. Er valt af te lezen dat 25 van de 32 ondernemingen acht of meer informatie-elementen ook in hun in Nederland gepubliceerde jaarrekening laten zien. Het merendeel van de ondernemingen brengt in het Form $20-\mathrm{F} / 10-\mathrm{K}$ en in de Nederlandse jaarrekening dezelfde informatie naar buiten. Hieronder bevinden

Tabel 5. Additionele informatieverschaffing in toelichting per informatie-element (totaal 32 ondernemingen)

\begin{tabular}{|c|c|c|c|}
\hline Informatie-element & $\begin{array}{c}\text { alleen in } \\
\text { Form 20-F/ 10-K }\end{array}$ & Ook in Nederlandse jaarrekening & Niet verstrekt \\
\hline Voorziening dubieuze debiteuren & 2 & 28 & 2 \\
\hline Pensioenkosten & 4 & 27 & 1 \\
\hline Pensioenvoorziening & 4 & 25 & 3 \\
\hline Belastinglasten & 5 & 26 & 1 \\
\hline Belastinglatenties & 5 & 27 & 0 \\
\hline Langetermijnschulden & 4 & 24 & 4 \\
\hline Operationele leaseverplichting & 2 & 28 & 2 \\
\hline Risico's financiële instrumenten & 0 & 25 & 7 \\
\hline Reële waarde financiële instrumenten & 1 & 25 & 6 \\
\hline Segmentatie naar bedrijfstak & 0 & 25 & 7 \\
\hline Segmentatie naar geografische gebied & 0 & 29 & 3 \\
\hline
\end{tabular}


zich 14 ondernemingen die ook bij het opstellen van de in Nederland gepubliceerde jaarrekening uitgaan van US GAAP. Zeven ondernemingen zijn minder bereid om toelichtingsinformatie, die zij uitsluitend op grond van US GAAP moeten verstrekken, tevens in de Nederlandse jaarrekening op te nemen.

Vergeleken met het onderzoek van Vergoossen (1996) is er behoorlijk wat veranderd. In het onderzoek van Vergoossen bestaan er grote verschillen in de mate waarin diverse informatie-elementen niet alleen in het Form 20-F/10-K, maar tevens in de Nederlandse jaarrekening worden verstrekt. Informatie omtrent bijvoorbeeld de hoogte van de voorziening dubieuze debiteuren wordt in het onderzoek van Vergoossen nog door 11 van de 15 ondernemingen alleen in het Form 20-F verstrekt, terwijl dat in het huidige onderzoek nog maar twee van de 32 ondernemingen zijn. Verder valt op dat de grote multinationale ondernemingen Unilever, Philips, AEGON, Akzo Nobel, Ahold en Reed Elsevier in het onderzoek van Vergoossen geen of slechts mondjesmaat additionele informatie die alleen op grond van US GAAP moet worden verstrekt in hun in Nederland gepubliceerde jaarrekening hebben opgenomen. Deze ondernemin-

Tabel 6. Additionele informatieverschaffing in de toelichting per onderneming (totaal 11 informatie-elementen)

\begin{tabular}{|c|c|c|c|}
\hline Onderneming & $\begin{array}{c}\text { alleen in } \\
\text { Form 20-F/ 10-K }\end{array}$ & Ook in Nederlandse jaarrekening & Niet verstrekt \\
\hline KLM & 4 & 4 & 3 \\
\hline KNPM & 0 & 11 & 0 \\
\hline Unilever & 0 & 11 & 0 \\
\hline Philips & 0 & 11 & 0 \\
\hline ASMI & 0 & 10 & 1 \\
\hline Océ & 6 & 3 & 2 \\
\hline AEGON & 0 & 11 & 0 \\
\hline Akzo Nobel & 4 & 7 & 0 \\
\hline Ahold & 0 & 11 & 0 \\
\hline Orthofix & 0 & 11 & 0 \\
\hline Sapiens & 0 & 11 & 0 \\
\hline Arcadis & 5 & 2 & 4 \\
\hline Reed Elsevier & 1 & 10 & 0 \\
\hline KPN & 0 & 11 & 0 \\
\hline ASML & 0 & 9 & 2 \\
\hline BESI & 0 & 9 & 2 \\
\hline Triple P & 0 & 7 & 4 \\
\hline Gucci & 0 & 11 & 0 \\
\hline Qiagen & 0 & 10 & 1 \\
\hline ABN Amro & 0 & 10 & 1 \\
\hline Chicago Bridge & 0 & 10 & 1 \\
\hline ING & 0 & 11 & 0 \\
\hline Core Laboratories & 0 & 11 & 0 \\
\hline Equant & 0 & 10 & 1 \\
\hline TPG & 0 & 10 & 1 \\
\hline $\mathrm{CNH}$ & 0 & 11 & 0 \\
\hline Crucell & 0 & 5 & 6 \\
\hline Head & 0 & 10 & 1 \\
\hline New Skies & 0 & 8 & 3 \\
\hline Buhrmann & 1 & 8 & 2 \\
\hline James Hardie & 0 & 11 & 0 \\
\hline Van der Moolen & 6 & 4 & 1 \\
\hline
\end{tabular}


gen publiceren nu bijna alle informatie-elementen ook in de Nederlandse jaarrekening.

De toegenomen informatieverschaffing houdt wellicht verband met Richtliin 380, 'Additionele informatieverschaffing vanwege buitenlandse noteringen', van de Raad voor de Jaarverslaggeving (RJ). In deze richtlijn beveelt de RJ aan om de additionele jaarrekeninginformatie die op grond van de voorschriften van de SEC moet worden verstrekt, tevens op te nemen in de jaarrekening zoals gepubliceerd in Nederland of om in die jaarrekening te vermelden dat Form 20-F is gedeponeerd bij de SEC en dat een gratis exemplaar bij de onderneming kan worden opgevraagd (RJ 380.103) ${ }^{6}$.

\section{Slotopmerkingen}

Op basis van de onderzoeksbevindingen kan worden geconcludeerd dat de Nederlandse ondernemingen met een beursnotering in de Verenigde Staten meer en meer waarderings- en resultaatbepalingsgrondslagen in hun in Nederland gepubliceerde jaarrekening toepassen die in overeenstemming zijn met US GAAP. Daarnaast komt er veel additionele informatie die in de Verenigde Staten verplicht is, ook steeds vaker terecht in de in Nederland gepubliceerde jaarrekening. Deze ontwikkelingen zijn voor een deel een uitvloeisel van de internationale harmonisatie van de verslaggevingsregels waar de Verenigde Staten een belangrijke stempel op drukken ${ }^{7}$.

Het aantal afwijkingen in de aansluitingsoverzichten wordt echter niet kleiner, maar neemt juist toe. Dit hangt samen met nieuwe regelgeving in de Verenigde Staten die niet of met vertraging - al dan niet via IFRS - in de Nederlandse regelgeving wordt geïncorporeerd. Bovendien worden grondslagwijzigingen vaak niet met terugwerkende kracht doorgevoerd waardoor de afwijkingen in de aansluitingsoverzichten niet verdwijnen, maar in de loop van de tijd wel steeds kleiner worden. In het kader van dit artikel zijn overigens onder meer de onderzoeken van Lang, Smith Raedy en Higgins Yetman (2003) en Lang, Lins en Miller (2003) interessant. Uit eerstgenoemd onderzoek blijkt namelijk dat buitenlandse ondernemingen met een beursnotering in de Verenigde Staten in hun eigen land kwalitatief betere informatie verschaffen dan ondernemingen zonder een dergelijke beursnotering. Zij zijn transparanter, doen minder aan winststuring en zijn eerder geneigd om slecht nieuws naar buiten te brengen via de jaarverslaggeving. In laatstgenoemd onderzoek komt naar voren dat ondernemingen met een beursnotering in de Verenigde Staten intensiever worden gevolgd door beleggingsanalisten en dat zij de waarde van die ondernemingen beter kunnen inschatten dan die van andere ondernemingen. De onderzoeksbevindingen ondersteunen de hypothese dat ondernemingen met een beursnotering in de Verenigde Staten informatie naar buiten brengen van een betere kwaliteit hetgeen leidt tot een hogere marktwaarde.

\section{Literatuur}

Knoops, C.D., (2004), Bijzondere waardeverminderingen: mogelijkheden tot resultaatsturing?, in: Maandblad voor Accountancy en Bedriffseconomie, jg. 78, nr.1/2, pp. 2-4.

Lang, M.H., K.V. Lins en D.P. Miller, (2003), ADRs, analysts, and accuracy: Does cross listing in the United States improve a firm's information environment and increase market value?, in: Journal of Accouning Research, jg. 41, nr. 2, pp. 317-345; C. Leuz, Discussion, pp. 347-362.

Lang, M.H., J. Smith Raedy en M. Higgins Yetman, (2003), How representative are firms that are cross-listed in the United States? An analysis of accounting quality, in: Journal of Accounting Research, jg. 41, nr. 2, pp. 363-386; P. Joos, Discussion, pp. 387-396.

Ucieda Blanco, J. en B. Garcia Osma, (2004), The comparability of International Accounting Standards and US GAAP: an empirical study of Form 20-F reconciliations, in: International Journal of Accounting, Auditing and Performance Evaluation, jg. 1, nr. 1, pp. 5-36.

Vergoossen, R.G.A., (1996), Invloed beursnotering in Verenigde Staten op stelselkeuze en additionele informatieverschaffing, in: Maandblad voor Accountancy en Bedrijfseconomie, jg. 70, nr. 11, pp. 597-608.

Vergoossen, R.G.A. en A.A.R. Polman, (1995), US GAAP en de jaarverslaggeving van Nederlandse ondernemingen, in: Maandblad voor Accountancy en Bedrijfseconomie, jg. 69, nr. 9, pp. 534-544.

Vergoossen, R.G.A. en B.A.J.J. Verhoofstad, (2003), Invloed US GAAP op eigen vermogen en nettoresultaat, in: J.B. Backhuijs, R.G. Bosman en C.D. Knoops, Het jaar 2002 verslagen: Onderzoek jaarverslaggeving Nederlandse ondernemingen, Kluwer/Koninklijk NIVRA, pp. 127-146.

\section{Noten}

1 Baan Company NV en PolyGram NV hadden ten tijde van het onderzoek van Vergoossen (1996) een beursnotering in de Verenigde Staten. Dit is inmiddels niet meer het geval.

2 Het gaat hier om 14 ondernemingen. De overige drie ondernemingen passen respectievelijk International Accounting Standards (IAS; tegenwoordig IFRS), Franse verslaggevingsregels en Australische verslaggevingsregels toe.

3 Zie Vergoossen en Verhoofstad (2003) voor een uitgebreide bespreking van het verloop van de effecten van de verschillen in de periode 1985-2002.

4 Zie ook Vergoossen en Polman (1995).

5 Vergoossen en Verhoofstad (2003) en Knoops (2004) gaan uitgebreid op deze effecten in.

6 Zie Vergoossen en Verhoofstad (2003) voor een nadere beschouwing over de toepassing van RJ 380.

7 Zie Ucieda Blanco en Garcia Osma (2004) voor een analyse van de invloed van verschillen tussen IAS en US GAAP op de gepresenteerde cijfers, zoals die blijken uit de Forms 20-F van niet-Amerikaanse ondernemingen met een beursnotering in de Verenigde Staten die IAS toepassen. 